\title{
Fire Resistance of Sewage Sludge Ash Blended Cement Pastes
}

\author{
M. A. Tantawy, A. M. El-Roudi, Elham M. Abdalla, and M. A. Abdelzaher \\ Chemistry Department, Faculty of Science, Minia University, Minia, Egypt
}

Correspondence should be addressed to M. A. Tantawy; matantawy75@yahoo.com

Received 1 September 2012; Accepted 15 December 2012

Academic Editor: Lucian Dascalescu

Copyright (c) 2013 M. A. Tantawy et al. This is an open access article distributed under the Creative Commons Attribution License, which permits unrestricted use, distribution, and reproduction in any medium, provided the original work is properly cited.

\begin{abstract}
The aim of the present study is to investigate the hydration characteristics and the fire resistance of sewage sludge ash blended cement pastes by the determination of compressive strength, bulk density, and total porosity in addition to XRD and SEM techniques. Sewage sludge ash modifies the hydration of cement because of its pozzolanic reaction with portlandite favoring the formation of crosslinked fibrous calcium silicate of low $\mathrm{Ca} / \mathrm{Si}$ ratio. Hence, it was concluded that thermal damage of cement pastes after the exposure to high treatment temperatures (i.e., crack formation and loss of mechanical properties) was effectively reduced with sewage sludge as content up to $20 \mathrm{wt} \%$ because of that the presence of crosslinked fibrous calcium silicate strengthens the cement matrix.
\end{abstract}

\section{Introduction}

Sewage water is the collection of wastewater effluents from domestic, hospital, commercial, and industrial establishments. The objective of the sewage treatment is to produce treated sewage water and sewage sludge suitable for safe discharge into the environment or reuse [1]. International environmental protection agencies recommended that incineration is an attractive disposal method of sewage sludge [2]. Sewage sludge ash has been used as an additive in the production of construction materials [3], mortars [4], and concrete [5]. The exposure of concrete to high temperatures as in an accidental fire of buildings leads to an undesirable structural quality deterioration [6]. Previous studies illustrate that hardened cement paste plays a key role in high temperatures deterioration process. The main damage mechanisms that discuss the deterioration of concrete at elevated temperatures are thermal mismatch, decomposition of hydrates, coarsening of pore structure, and pore pressure effects [7].

Siliceous aggregates expand around $575^{\circ} \mathrm{C}$ as a result of the $\alpha$ - $\beta$ quartz inversion, whereas cement paste shrinks above $200^{\circ} \mathrm{C}$ [8]. This thermal mismatch (i.e., expansion of siliceous aggregate and shrinkage of cement paste matrix) causes a considerable tension at the aggregate-matrix interface leading eventually to interface fracture and cracking [9]. The decomposition of hydrates occurs during the thermal damage of cementitious materials including the decomposition of ettringite, $\mathrm{C}-\mathrm{S}-\mathrm{H}$, and carboaluminate hydrates at $180-450^{\circ} \mathrm{C}$ and portlandite at $425-580^{\circ} \mathrm{C}$ [10]. The decomposition of portlandite damages the C-S-H. The decomposition of hydrates decreases stiffness and strength of cementitious materials. Volume reduction of the hydrated phases because of the loss of bound water leads to air void formation and coarsening of pore structure of cementitious materials that in turn cause cracking and a considerable loss of the mechanical properties of cementitious materials at a high temperature attack $[11,12]$. Free water of saturated cement paste expands and evaporates at about the boiling point of water. The low permeability of cement paste prevents water vapor from escaping through closed pores leading to the buildup of internal pore pressure and the accumulation of tensions in the block sample. The low tensile strength of cement paste under these conditions leads to the formation of microcracks and significant mechanical damage [13, 14].

The cracking of cementitious materials exposed to a high temperature attack develops during the postcooling period as a result of rehydration of dissociated $\mathrm{CaO}$ associated with a significant volume increase of about $44 \%$ [15]. The enhancement of the thermal stability of a concrete and the reduction of postcooling cracking have been achieved by the addition of pozzolana that consumes portlandite $\left(\mathrm{Ca}(\mathrm{OH})_{2}\right)$ liberated from the hydration of ordinary Portland cement 
TABLE 1: Mix composition of sewage sludge ash blended cements.

\begin{tabular}{lcc}
\hline Symbol & OPC, wt $\%$ & Sewage sludge ash, wt $\%$ \\
\hline C & 100 & 0 \\
S1 & 95 & 5 \\
S2 & 90 & 10 \\
S3 & 85 & 15 \\
S4 & 80 & 20 \\
\hline
\end{tabular}

(OPC) forming additional calcium silicate hydrates [16]. The replacement of OPC by silica fume [17], fly ash [16, 18], metakaolin [17, 19], homra [20], and granulated blast furnace slag [9] was found to improve the physicomechanical properties, microstructure, and thermal stability of cementitious materials as well as reduce the extent of cracking when exposed to high temperatures. The addition of polypropylene fibers also was found to reduce the damage of self-compacting cement paste because melted polypropylene fibers form a connected pore structure through which the heat and water vapor escapes [21]. It was indicated that sewage sludge ash has a high pozzolanic activity and improves the workability and compressive strength of concrete [22]. There are lakes of knowledge in the literature about the fire resistance of cementitious materials containing sewage sludge ash. Hence, the present study aims to investigate the influence of sewage sludge ash in the fire resistance of hardened cement pastes.

\section{Materials and Experimental Techniques}

Raw materials used in this work were OPC CEM I (no.42.5) and raw sewage sludge from a wastewater treatment facility. Raw sewage sludge was dried, incinerated in an electrical muffle furnace with a heating rate $10^{\circ} \mathrm{C} / \mathrm{min}$ up to $800^{\circ} \mathrm{C}$ with soaking time for $2 \mathrm{hrs}$, recharged from the muffle furnace, cooled to room temperature in desiccator, and ground to pass $90 \mu \mathrm{m}$ sieve. These values of parameters were selected because incineration of sewage sludge must be optimized at $800^{\circ} \mathrm{C}$ to preserve the pozzolanic activity of the resultant ash as described elsewhere [23]. Sewage sludge ash blended cement was prepared by a partial replacement of OPC with 5-20 wt\% sewage sludge ash and their mix composition are shown in Table 1 .

Cement pastes were mixed using a water/cement ratio of about 0.25 . Freshly prepared cement pastes were moulded in $2 \mathrm{~cm}^{3}$ stainless steel cubic moulds at about $100 \%$ relative humidity and demolded after 24 hrs. Hydration characteristics were investigated for cement pastes cured up to 90 days under tap water. The bulk density was determined according to the Archimedes principle [24]. The compressive strength was measured using a manual compressive strength machine according to ASTM designation [25]. Stopping of the hydration of cement pastes at 3, 7, 28, and 90 days as well as free water content determination were performed using a domestic microwave oven as described elsewhere [26].

The combined water content was determined for stopped samples from weight loss after ignition in porcelain crucibles

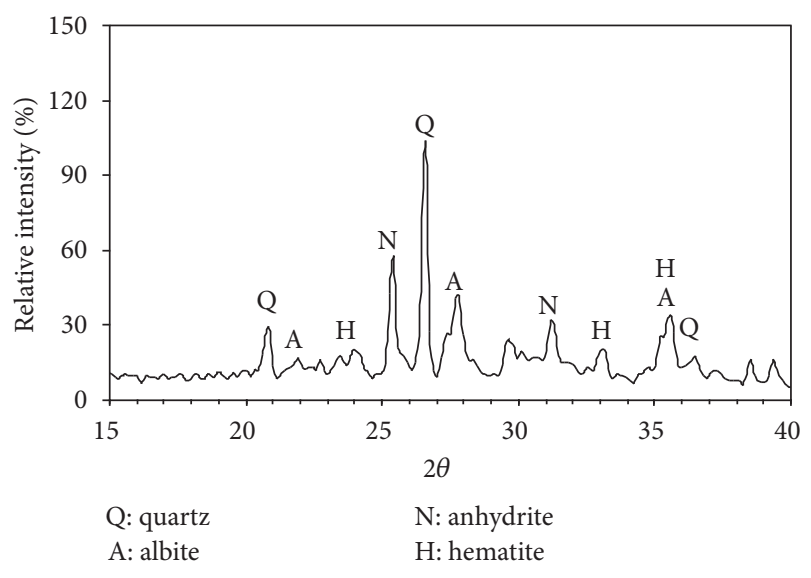

FIGURE 1: The XRD pattern of sewage sludge ash.

at $1000^{\circ} \mathrm{C}$ for $1 \mathrm{hr}$ in a muffle furnace. The total porosity of the hardened cement paste is calculated from the values of bulk density, free and total water contents as described elsewhere [27]. Fire resistance was investigated for cement pastes hydrated for 28 days and dried at $105^{\circ} \mathrm{C}$ for $24 \mathrm{hrs}$ then heat treated from 200 up to $800^{\circ} \mathrm{C}$. The firing program was carried out in a muffle furnace with a rate of $10^{\circ} \mathrm{C} / \mathrm{min}$ for $2 \mathrm{hrs}$ at each temperature and cooled to room temperature in desiccator. The compressive strength of heat treated cement pastes was measured as mentioned above. The bulk density and total porosity were calculated according to the ISO 5018-1983 [28]. X-ray fluorescence analysis (XRF) of fine powdered samples was carried out for finely ground selected samples by Philips PW1606 X-ray fluorescence spectrometer. $\mathrm{X}$-ray diffraction analysis (XRD) was carried out for finely ground selected samples by Philips X-ray diffractometer PW 1370, Co with Ni filtered $\mathrm{CuK}_{\alpha}$ radiation (1.5406 ̊̊). Fourier transform infrared analysis (FTIR) was measured for finely ground selected samples by spectrometer Perkin Elmer FTIR System Spectrum X in the range $400-4000 \mathrm{~cm}^{-1}$. Scanning electron microscope analysis (SEM) was investigated for chips of selected samples by Jeol-Dsm 5400 LG apparatus.

\section{Results and Discussion}

3.1. Characterization of Sewage Sludge Ash. Table 2 illustrates the chemical composition of OPC and sewage sludge ash determined by XRF analysis. The sum of $\mathrm{SiO}_{2}, \mathrm{Al}_{2} \mathrm{O}_{3}$, and $\mathrm{Fe}_{2} \mathrm{O}_{3}$ content of sewage sludge ash is in accordance with requirements of ASTM designation for pozzolana [29]. Sewage sludge ash has high $\mathrm{Al}_{2} \mathrm{O}_{3}, \mathrm{Fe}_{2} \mathrm{O}_{3}$, and $\mathrm{CaO}$ contents due to the use of alum, ferric salts, and lime in the wastewater treatment. Loss on ignition LOI is possibly due to incomplete incineration and adsorbed water. Table 3 illustrates the phase composition of OPC, wt\% according to Bouge's calculations [10]. Figure 1 illustrates the XRD patterns of sewage sludge ash. Sewage sludge ash contains quartz as the main phase in addition to anhydrite, albite, and hematite minerals. Figure 2 illustrates the FTIR spectra of sewage sludge ash. The absorption bands of silica appear at 1101, 796, and $467 \mathrm{~cm}^{-1}$ corresponding to the asymmetric stretching vibration of 
TABLE 2: Chemical composition of OPC and sewage sludge ash, wt\%.

\begin{tabular}{|c|c|c|c|c|c|c|c|c|c|c|c|c|}
\hline \multirow{2}{*}{ Material } & \multicolumn{12}{|c|}{ Oxide, $w t \%$} \\
\hline & $\mathrm{SiO}_{2}$ & $\mathrm{Al}_{2} \mathrm{O}_{3}$ & $\mathrm{Fe}_{2} \mathrm{O}_{3}$ & $\mathrm{CaO}$ & $\mathrm{MgO}$ & $\mathrm{SO}_{3}$ & $\mathrm{Na}_{2} \mathrm{O}$ & $\mathrm{K}_{2} \mathrm{O}$ & LOI $^{*}$ & $\mathrm{P}_{2} \mathrm{O}_{5}$ & Not determined & Total \\
\hline $\mathrm{OPC}$ & 20.88 & 6.08 & 3.18 & 63.00 & 1.50 & 1.60 & 0.22 & 0.24 & 1.35 & 0.15 & 1.80 & 98.20 \\
\hline Sewage sludge ash & 53.90 & 9.13 & 8.05 & 6.80 & 3.93 & 6.04 & 1.43 & 1.62 & 1.11 & 7.12 & 0.74 & 99.26 \\
\hline
\end{tabular}

${ }^{*} \mathrm{LOI}$ is the loss on ignition.

TABle 3: Phase composition of OPC according to Bouge's calculations.

\begin{tabular}{lc}
\hline Phase & Content, wt $\%$ \\
\hline $\mathrm{C}_{3} \mathrm{~S}$ & 47.8 \\
$\beta-\mathrm{C}_{2} \mathrm{~S}$ & 24.1 \\
$\mathrm{C}_{3} \mathrm{~A}$ & 10.7 \\
$\mathrm{C}_{4} \mathrm{AF}$ & 9.7 \\
\hline
\end{tabular}

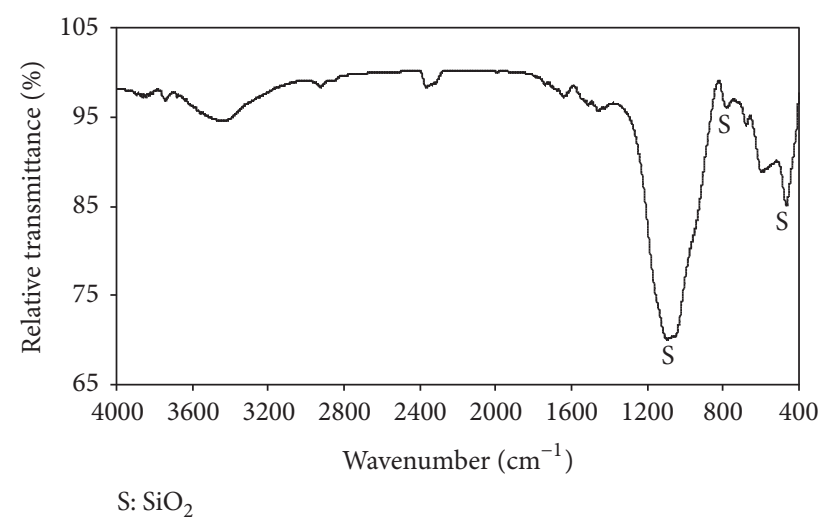

FIGURE 2: The FTIR spectra of sewage sludge ash.

$\mathrm{Si}-\mathrm{O}-\mathrm{Si}$, symmetric stretching vibration of $\mathrm{Si}-\mathrm{O}-\mathrm{Si}$, and bending vibration of $\mathrm{O}-\mathrm{Si}-\mathrm{O}$, respectively [30].

\subsection{Hydration Characteristics of Blended Cement Pastes.} Figures 3 and 4 illustrate the compressive strength and combined water contents of sewage sludge ash blended cement pastes, respectively. The compressive strength and the combined water content decrease with sewage sludge ash content because of the replacement of OPC with sewage sludge ash that have no cementations properties. This is mainly due to the crystalline structure of the sewage sludge ash that has slight pozzolanic activity and the decrease of OPC portion. The decrease of OPC content decreases the formation of C-S-H in the hydrated pastes that has the main binding properties. The rate of compressive strength and the combined water content of sewage sludge ash blended cement pastes increase markedly at later ages of hydration because sewage sludge ash acts as a filler at early ages. The accumulation of portlandite liberated from the hydration process in the pore solution of cement paste at later ages activates the slow pozzolanic reaction of sewage sludge ash with portlandite forming additional hydration products.

Figure 5 illustrates the bulk density and total porosity of sewage sludge ash blended cement pastes. The bulk density

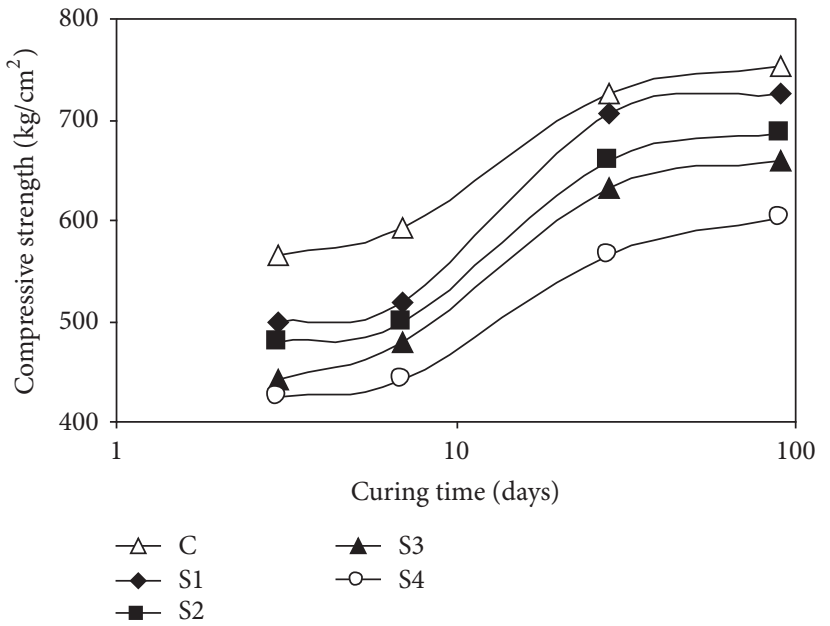

FIGURE 3: The compressive strength of sewage sludge ash blended cement pastes.

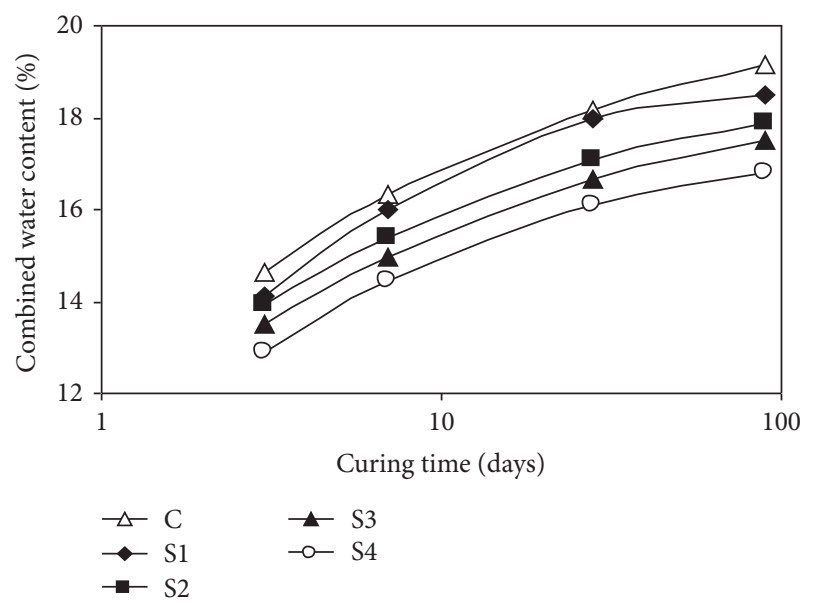

FIGURE 4: The combined water content of sewage sludge ash blended cement pastes.

decreases, whereas the total porosity increases with sewage sludge ash content due to the decrease of OPC as a result of replacement with sewage sludge ash. Figure 6 illustrates the XRD patterns of OPC and sewage sludge ash blended cement pastes hydrated for 28 days. Hydrated OPC paste contains a mixture of unhydrated cement clinker phases $\beta-C_{2} S$ and $C_{3} S$ in addition to portlandite that liberated from hydration process. Calcite appears in hydrated cement pastes because of the partial carbonation of portlandite. Wollastonite appears in sewage sludge ash blended cement pastes. The content of portlandite reduced in sewage sludge 


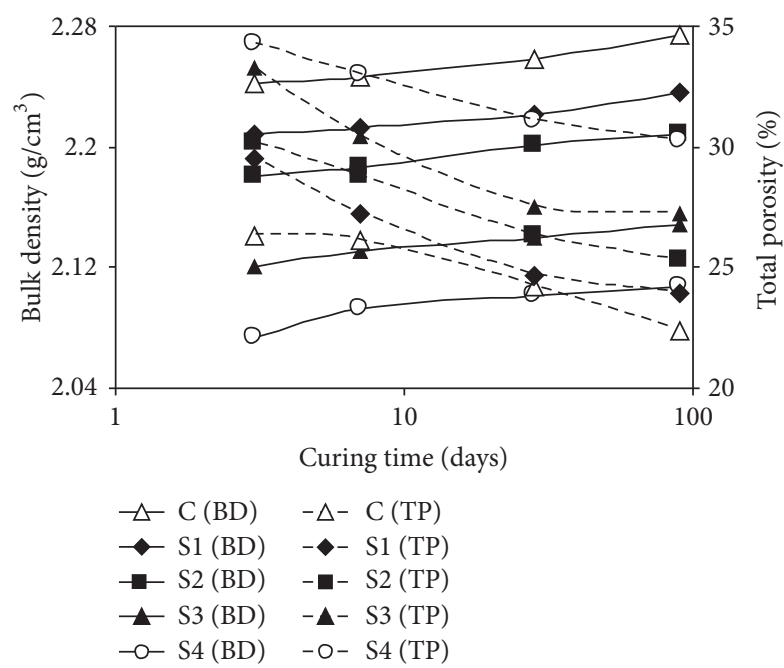

FIgURE 5: The bulk density and the total porosity of sewage sludge ash blended cement pastes.

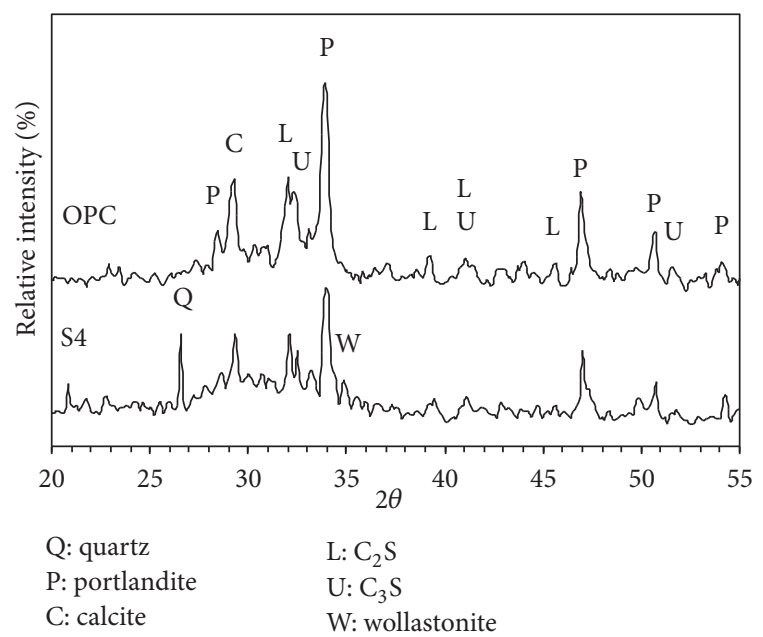

FIGURE 6: The XRD patterns of OPC and sewage sludge ash blended cement pastes hydrated for 28 days.

ash blended cement pastes because of the pozzolanic activity and the dilution effect of sewage sludge ash that replaces OPC. Blending cement with sewage sludge ash modifies the hydration reaction mechanism by favoring the formation of calcium silicate hydrates with low $\mathrm{Ca} / \mathrm{Si}$ ratio because the addition of sewage sludge ash lowers the $\mathrm{Ca} / \mathrm{Si}$ ratio in the pore solution of hydrating cement paste [31]. Figure 7 illustrates the SEM micrograph of sewage sludge ash blended cement paste (S4) hydrated for 28 days. Sewage sludge ash reacts with portlandite liberated from cement hydration because of the pozzolanic activity forming crosslinked fibrous calcium silicate.

3.3. Fire Resistance of Blended Cement Pastes. Figure 8 illustrates the compressive strength of sewage sludge ash blended cement pastes fired from 200 up to $800^{\circ} \mathrm{C}$. The compressive strength of OPC increases gradually after firing up to $400^{\circ} \mathrm{C}$ then decreases sharply. The increase in compressive strength

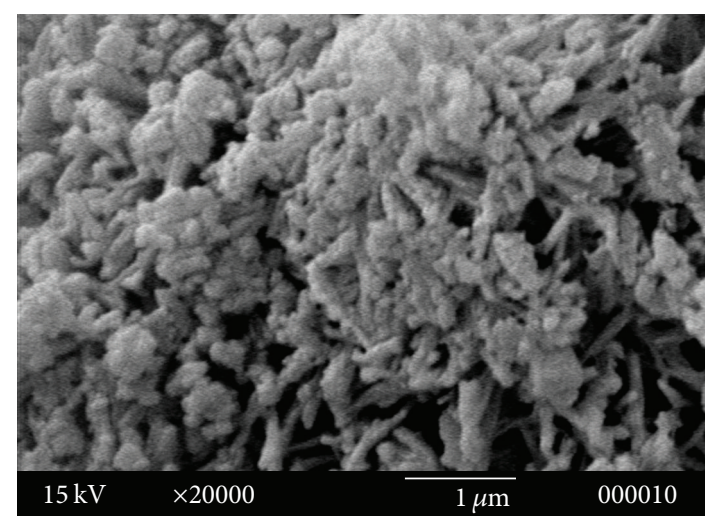

FIGURE 7: The SEM micrograph of sewage sludge ash blended cement paste (S4) hydrated for 28 days.

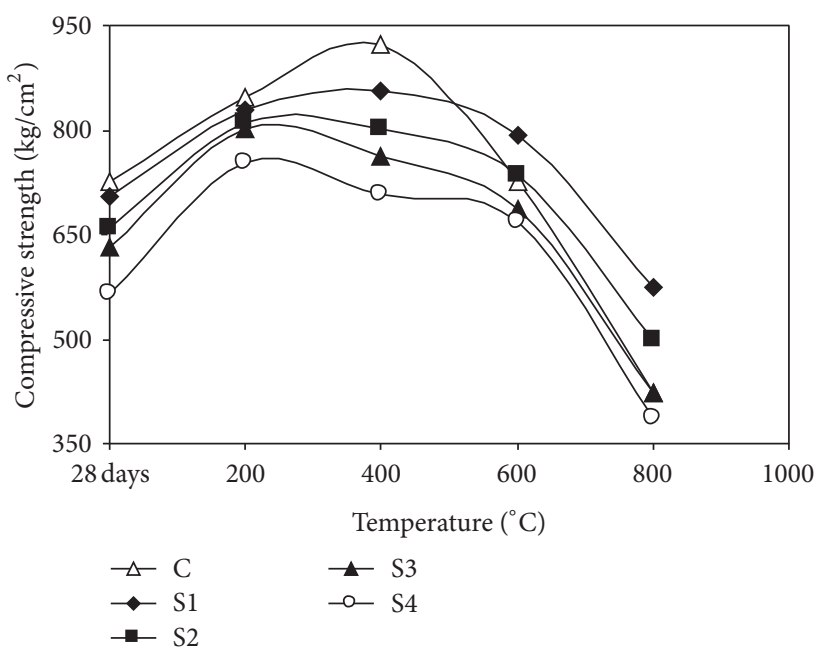

FIGURE 8: The compressive strength of sewage sludge ash blended cement paste fired at $200-800^{\circ} \mathrm{C}$.

may be due to the self-autoclaving effect that occurs during firing. Water vapor evolved as a result of the partial decomposition of hydration products entrapped inside hardened cement paste due to low porosity. This hydrothermal condition enhances the hydration of unhydrated cement grains (i.e., $\beta-\mathrm{C}_{2} \mathrm{~S}$ and $\mathrm{C}_{3} \mathrm{~S}$ ) forming additional amounts of $\mathrm{C}$ $\mathrm{S}-\mathrm{H}$ [32]. The compressive strength of sewage sludge ash blended cement pastes fired at 200 and $400^{\circ} \mathrm{C}$ are lower than that of OPC paste. This is due to dilution of OPC with sewage sludge ash. The self-autoclaving effect diminishes inside sewage sludge ash blended cement pastes that have a higher porosity compared to OPC paste as indicated from Figure 9 that illustrates lower bulk density and higher total porosity of sewage sludge ash blended cement pastes fired at $200-800^{\circ} \mathrm{C}$. Thus water vapor escapes easily through open pores inside sewage sludge ash hardened cement pastes. This is also due to that the sewage sludge ash is mainly composed of crystalline silica with low pozzolanic activity, then the hydration products especially C-S-H decrease, that is, the main source of compressive strength. On contrast, the compressive strength of sewage sludge ash blended cement 


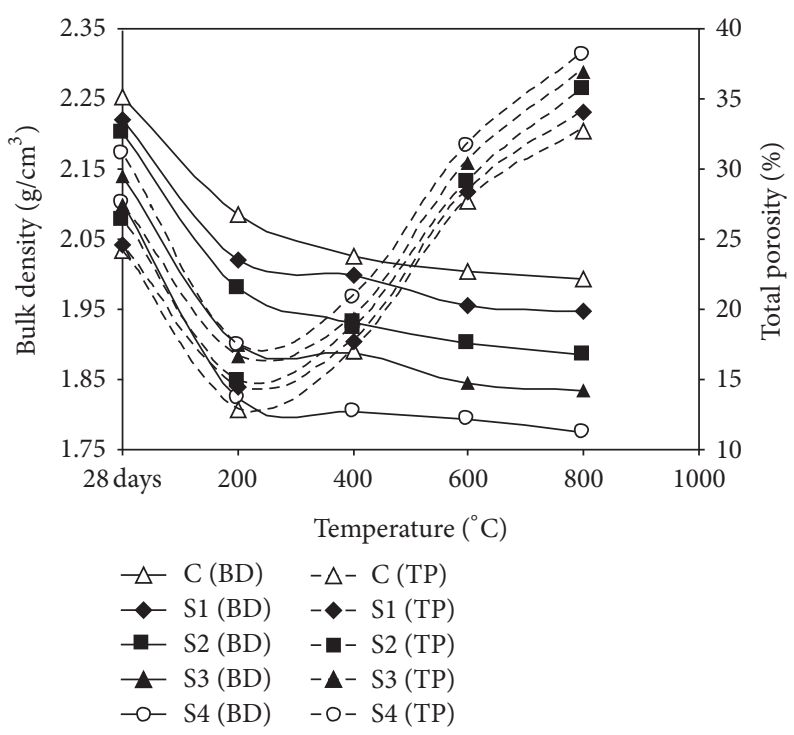

FIgURE 9: The bulk density and total porosity of sewage sludge ash blended cement pastes fired at $200-800^{\circ} \mathrm{C}$.

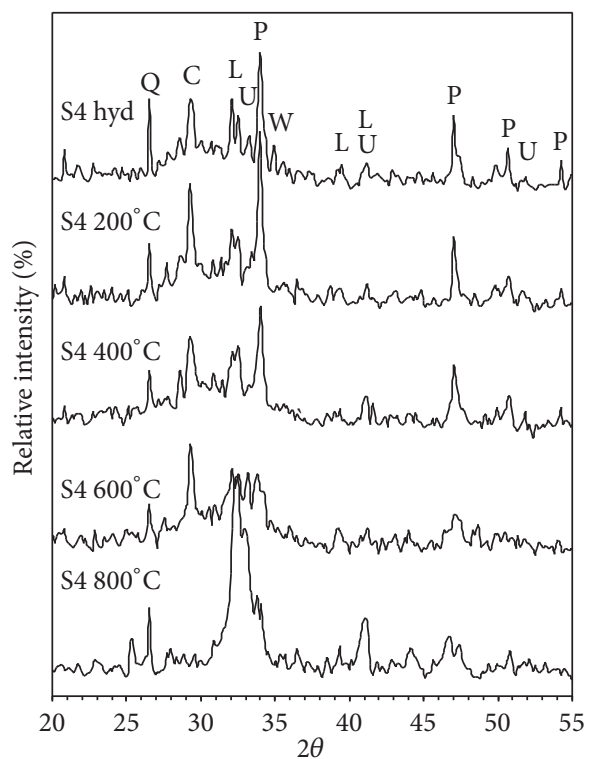

FIgURE 10: The XRD patterns of sewage sludge ash blended cement paste (S4) fired at different temperatures $200-800^{\circ} \mathrm{C}$.

pastes fired at $600-800^{\circ} \mathrm{C}$ is higher than that of OPC paste. The crosslinked fibrous calcium silicate formed because of the pozzolanic activity of sewage sludge ash strengthen the cement matrix and improves the mechanical properties of cement paste exposed to high temperatures.

Figure 10 illustrates the XRD patterns of sewage sludge ash blended cement paste (S4) fired at different temperatures $200-800^{\circ} \mathrm{C}$. Portlandite partially decomposes after firing up to $600^{\circ} \mathrm{C}$ and completely at $800^{\circ} \mathrm{C}$, whereas calcite decomposes at $800^{\circ} \mathrm{C}$. The hump in the range $25-352 \theta$ due to $\mathrm{C}-\mathrm{S}-\mathrm{H}$ still appears after firing at $600^{\circ} \mathrm{C}$ and completely disappears at $800^{\circ} \mathrm{C}$. The content of anhydrous calcium silicate minerals $\beta-C_{2} S$ and $C_{3} S$ increases due to the decomposition of C-S$\mathrm{H}$. This proves that $\mathrm{C}-\mathrm{S}-\mathrm{H}$ decomposes over a wide range temperature due to its amorphous nature. The decomposition of C-S-H after $600^{\circ} \mathrm{C}$ leads to the loss of the mechanical properties of cement pastes. Figure 11 illustrates the SEM micrographs of sewage sludge ash blended cement paste (S4) fired at $200-800^{\circ} \mathrm{C}$ as well as OPC paste fired at $600^{\circ} \mathrm{C}$. Amorphous C-S-H still appears as a dense cement matrix in hardened cement pastes fired at $200^{\circ} \mathrm{C}$. Partial decomposition of portlandite starts at $400^{\circ} \mathrm{C}$ accompanying with coarsening of the pore structure of cement paste and formation of microcracks around portlandite crystals. Firing OPC paste at $600^{\circ} \mathrm{C}$ leads to decomposition of the cementitious materials as well as the formation of friable cement matrix. The thermal damage of sewage sludge ash blended cement paste at $600^{\circ} \mathrm{C}$ was significantly reduced due to the presence of crosslinked fibrous calcium silicate.

\section{Conclusions}

(1) Sewage sludge ash contains quartz, anhydrite, gypsum, albite, and hematite minerals and its content of $\mathrm{SiO}_{2}, \mathrm{Al}_{2} \mathrm{O}_{3}$, and $\mathrm{Fe}_{2} \mathrm{O}_{3}$ is in accordance with requirements of ASTM designation for pozzolana.

(2) Sewage sludge ash slightly modifies the hydration reaction mechanism as a result of its low pozzolanic reaction with portlandite liberated from cement hydration favoring the formation of crosslinked fibrous calcium silicate of low $\mathrm{Ca} / \mathrm{Si}$ ratio.

(3) Decomposition of portlandite and C-S-H at $600^{\circ} \mathrm{C}$ leads to the buildup of internal pore pressure, coarsening of the pore structure of cement paste, the formation of micro cracks, and the loss of the mechanical properties of cement paste.

(4) The thermal damage of cement pastes exposed to high temperatures (i.e., the buildup of internal pore pressure, crack formation, and loss of mechanical properties) was effectively reduced with sewage sludge 


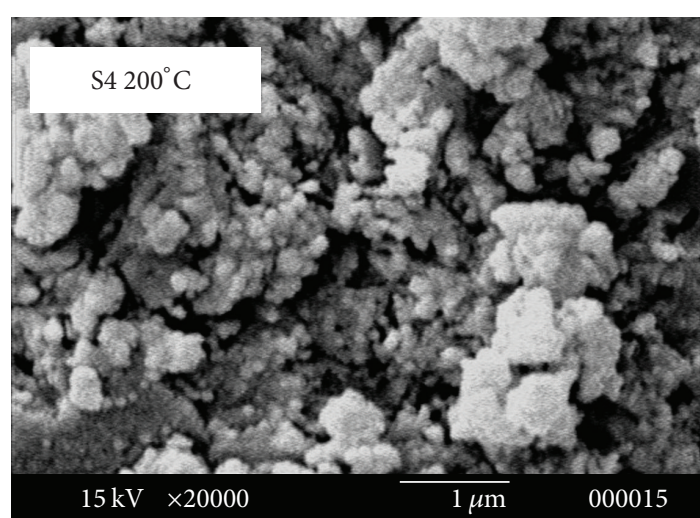

(a)

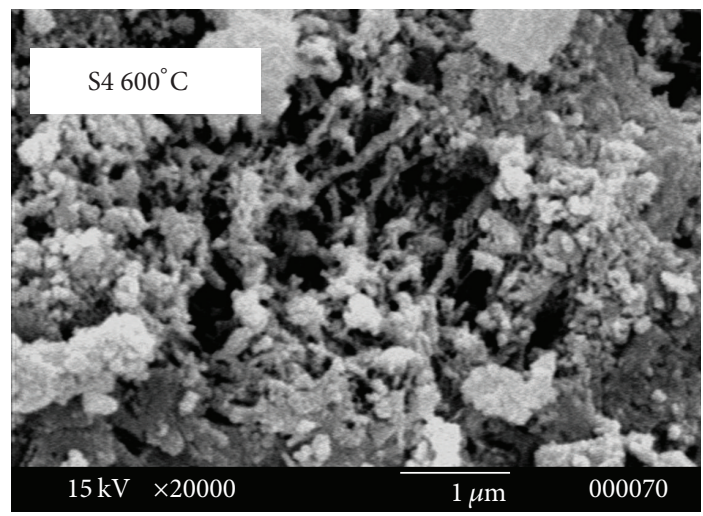

(c)

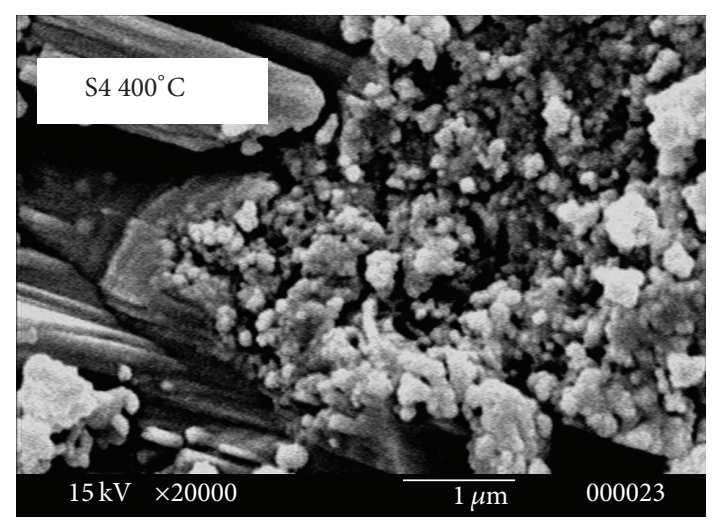

(b)

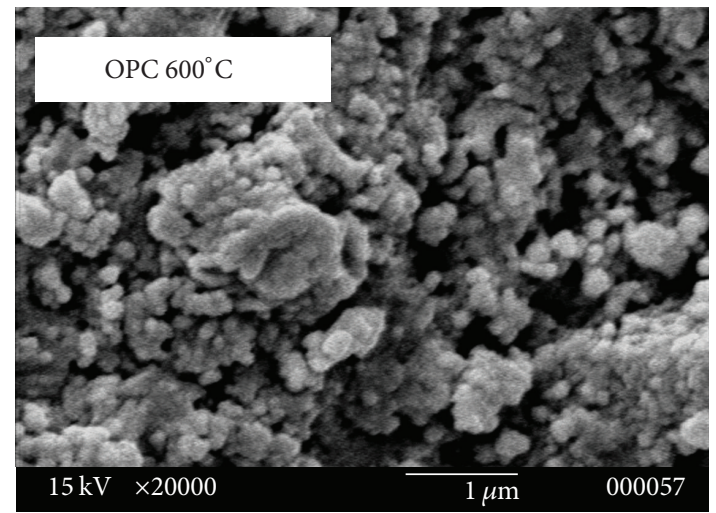

(d)

FIGURE 11: The SEM micrographs of sewage sludge ash blended cement paste (S4) fired at $200-800^{\circ} \mathrm{C}$ as well as $\mathrm{OPC}$ paste fired at $600^{\circ} \mathrm{C}$.

ash addition up to $20 \mathrm{wt} \%$ due to the presence of crosslinked fibrous calcium silicate which strengthens the cement matrix.

\section{References}

[1] L. S. Clescerl, A. E. Greenberg, and A. D. Eaton, Standard Methods for Examination of Water and Wastewater, American Public Health Association, Washington, DC, USA, 20th edition, 1987.

[2] O. Malerius and J. Werther, "Modeling the adsorption of mercury in the flue gas of sewage sludge incineration," Chemical Engineering Journal, vol. 96, no. 1-3, pp. 197-205, 2003.

[3] M. T. Ali and W. F. Chang, "Strength properties of cementstabilized municipal solid waste incinerator ash masonry bricks," American Concrete Institute, Materials, vol. 91, no. 3, pp. 256-263, 1994.

[4] J. Monzó, J. Paya, M. V. Borrachero, and A. Córcoles, "Use of sewage sludge ash(SSA)-cement admixtures in mortars," Cement and Concrete Research, vol. 26, no. 9, pp. 1389-1398, 1996.

[5] J. H. Tay, W. K. Yip, and K. Y. Show, "Clay-blended sludge as lightweight aggregate concrete material," Journal of Environmental Engineering, vol. 117, no. 6, pp. 834-844, 1991.

[6] C. S. Poon, S. Azhar, M. Anson, and Y. L. Wong, "Performance of metakaolin concrete at elevated temperatures," Cement and Concrete Composites, vol. 25, no. 1, pp. 83-89, 2003.
[7] G. A. Khoury, "Compressive strength of concrete at high temperatures: a reassessment," Magazine of Concrete Research, vol. 44, no. 6, p. 291, 1992.

[8] Y. F. Fu, Y. L. Wong, C. S. Poon, C. A. Tang, and P. Lin, "Experimental study of micro/macro crack development and stress-strain relations of cement-based composite materials at elevated temperatures," Cement and Concrete Research, vol. 34, no. 5, pp. 789-797, 2004.

[9] H. Y. Wang, "The effects of elevated temperature on cement paste containing GGBFS," Cement and Concrete Composites, vol. 30, no. 10, pp. 992-999, 2008.

[10] H. F. W. Taylor, Cement Chemistry, Thomas Telford, London, UK, 2nd edition, 1997.

[11] I. Janotka and T. Nürnbergerová, "Effect of temperature on structural quality of the cement paste and high-strength concrete with silica fume," Nuclear Engineering and Design, vol. 235, no. 17-19, pp. 2019-2032, 2005.

[12] G. F. Peng and Z. S. Huang, "Change in microstructure of hardened cement paste subjected to elevated temperatures," Construction and Building Materials, vol. 22, no. 4, pp. 593-599, 2008.

[13] M. Castellote, C. Alonso, C. Andrade, X. Turrillas, and J. Campo, "Composition and microstructural changes of cement pastes upon heating, as studied by neutron diffraction," Cement and Concrete Research, vol. 34, no. 9, pp. 1633-1644, 2004.

[14] H. Ai, J. F. Young, and G. W. Scherer, "Thermal expansion kinetics: Method to measure permeability of cementitious 
materials: II, Application to hardened cement pastes," Journal of the American Ceramic Society, vol. 84, no. 2, pp. 385-391, 2001.

[15] A. Petzold and M. Rohr, Concrete for High Temperatures, Maclaren and Sons, London, UK, 1970.

[16] Y. Xu, Y. L. Wong, C. S. Poon, and M. Anson, "Influence of PFA on cracking of concrete and cement paste after exposure to high temperatures," Cement and Concrete Research, vol. 33, no. 12, pp. 2009-2016, 2003.

[17] M. M. Morsy, S. S. Shebl, and A. M. Rashad, "Effect of fire on microstructure and mechanical properties of blended cement pastes containing metakaolin and silica fume," Asian Journal of Civil Engineering, vol. 9, no. 2, p. 93, 2008.

[18] H. El-Didamony, E. Abd El-Rahman, and R. M. Osman, "Fire resistance of fired clay bricks-fly ash composite cement pastes," Ceramics International, vol. 38, p. 201, 2012.

[19] D. D. Vu, P. Stroeven, and V. B. Bui, "Strength and durability aspects of calcined kaolin-blended Portland cement mortar and concrete," Cement and Concrete Composites, vol. 23, no. 6, pp. 471-478, 2001.

[20] M. Heikal, "Effect of temperature on the physico-mechanical and mineralogical properties of Homra pozzolanic cement pastes," Cement and Concrete Research, vol. 30, no. 11, pp. 1835-1839, 2000.

[21] X. Liu, G. Ye, G. De Schutter, Y. Yuan, and L. Taerwe, “On the mechanism of polypropylene fibres in preventing fire spalling in self-compacting and high-performance cement paste," Cement and Concrete Research, vol. 38, no. 4, pp. 487-499, 2008.

[22] C. M. A. Fontes, M. C. Barbosa, R. D. T. Filho, and J. P. Goncalves, "Potentiality of sewage sludge ash as mineral additive in cement mortar and high performance concrete," in Proceedings of the International RILEM Conference on the Use of Recycled Materials in Buildings and Structures, p. 797, Barcelona, Spain, 2004.

[23] M. A. Tantawy, A. M. El-Roudi, E. M. Abdalla, and M. A. Abdelzaher, "Evaluation of the pozzolanic activity of sewage sludge ash," ISRN Chemical Engineering, vol. 2012, Article ID 487037, 8 pages, 2012.

[24] R. de’ Gennaro, P. Cappelletti, G. Cerri, M. de’ Gennaro, M. Dondi, and A. Langella, "Zeolitic tuffs as raw materials for lightweight aggregates," Applied Clay Science, vol. 25, no. 1-2, pp. 71-81, 2004.

[25] ASTM Designation: C109-80, "Standard test methods for compressive strength of hydraulic cements," Annual Book of ASTM Standards, 1983.

[26] J. Pavlik, V. Tydlitat, R. Cerny, T. Klecka, P. Bouska, and P. Rovnanikova, "Application of a microwave impulse technique to the measurement of free water content in early hydration stages of cement paste," Cement and Concrete Research, vol. 33, p. $93,2003$.

[27] L. E. Copeland and T. C. Hayes, "Porosity of hardened Portland cement pastes," American Concrete Institute, Materials, vol. 27, p. $633,1956$.

[28] ISO 5018:1983, "Determination of true density of refractory and other raw materials".

[29] ASTM Designation: C 618-89, "Standard specification for coal fly ash and raw or calcined natural pozzolana for use as a mineral admixture in concrete," Annual Book of ASTM standards, 1998.

[30] K. Baltakys, R. Jauberthie, R. Siauciunas, and R. Kaminskas, "Influence of modification of $\mathrm{SiO}_{2}$ on the formation of calcium silicate hydrate," Materials Science- Poland, vol. 25, no. 3, pp. 663-670, 2007.
[31] Y. N. Chan, G. F. Peng, and M. Anson, "Residual strength and pore structure of high-strength concrete and normal strength concrete after exposure to high temperatures," Cement and Concrete Composites, vol. 21, no. 1, pp. 23-27, 1999.

[32] C. Alonso and L. Fernandez, "Dehydration and rehydration processes of cement paste exposed to high temperature environments," Journal of Materials Science, vol. 39, no. 9, pp. 3015-3024, 2004. 

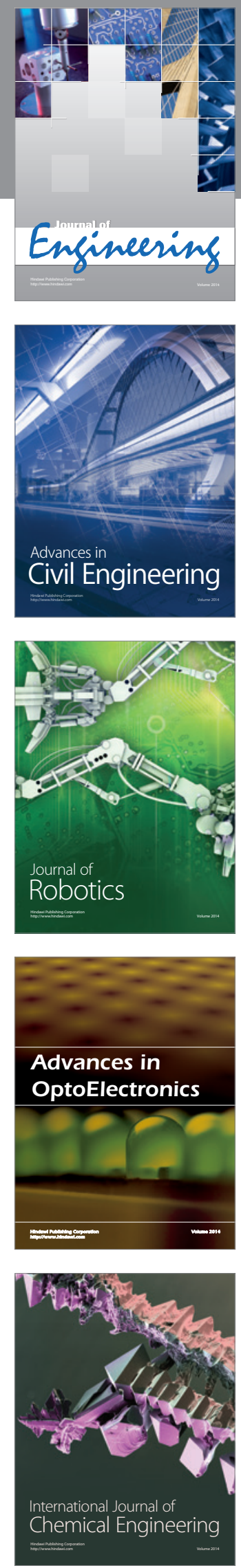

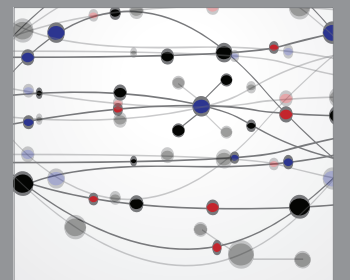

The Scientific World Journal
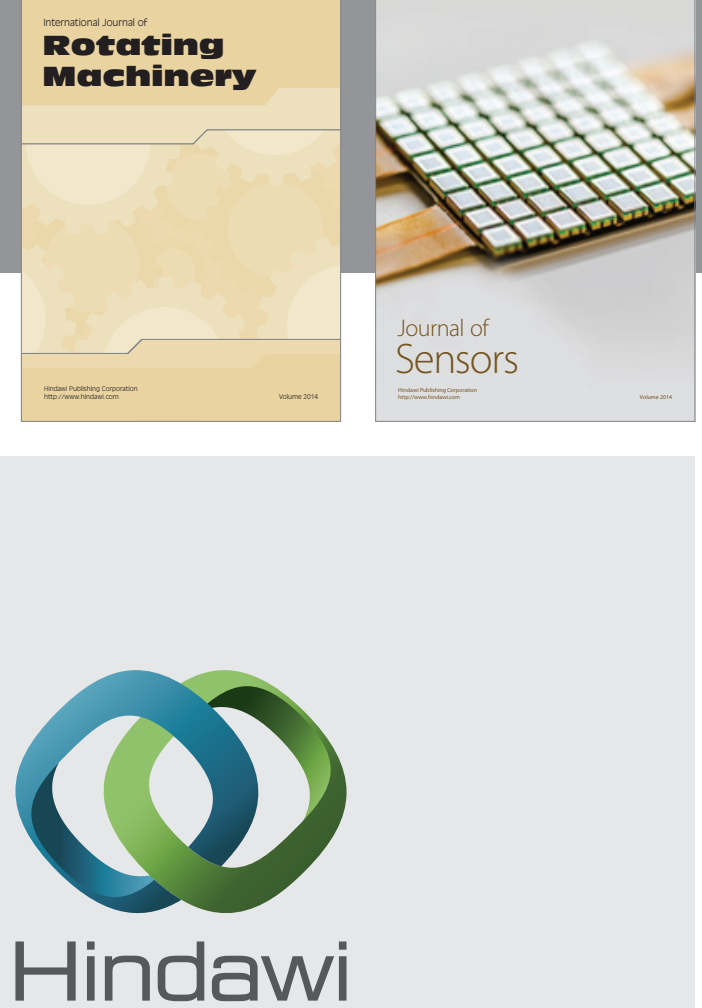

Submit your manuscripts at http://www.hindawi.com
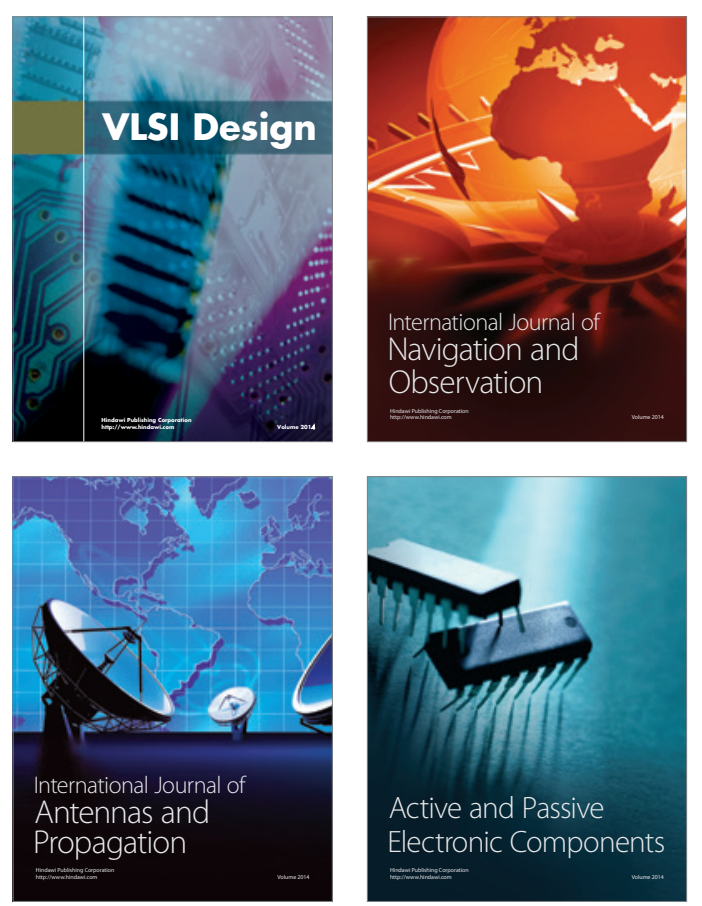
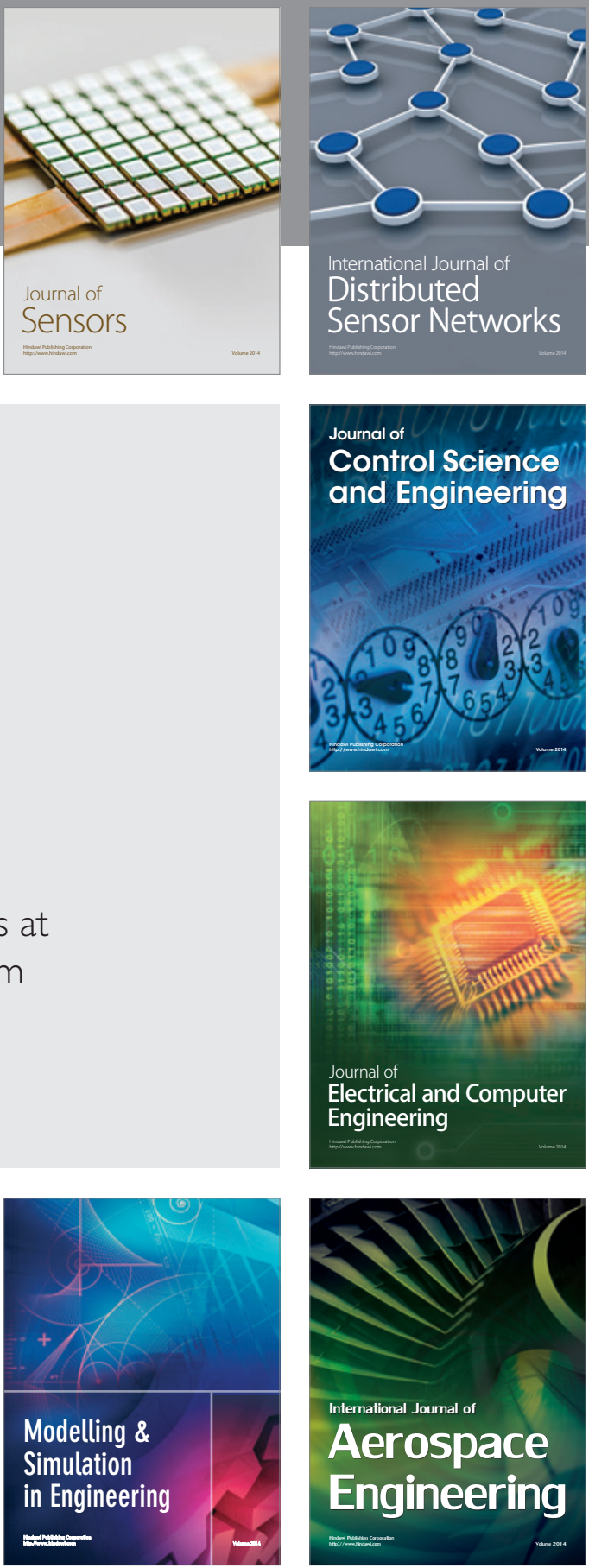

Journal of

Control Science

and Engineering
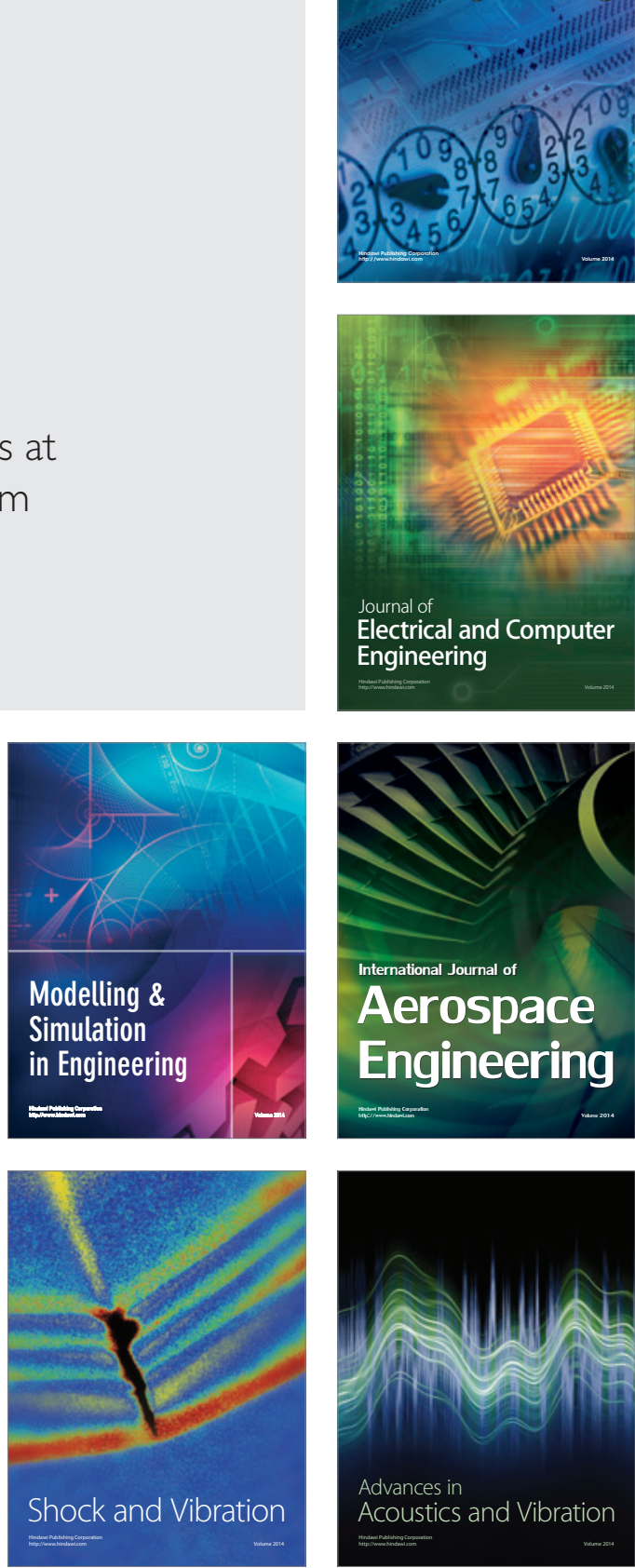